\title{
STUDENTS' PERCEPTION ON EDUCATIONAL ENVIRONMENT OF THE POSTGRADUATE PROGRAMME IN SELECTED NURSING COLLEGES OF NEPAL
}

Archana Pandey Bista ${ }^{1, *}$, Kalpana Sharma ${ }^{2}$, Neeta Tamrakar ${ }^{3}$, Muna Sharma ${ }^{4}$, Tilrupa Bhattarai ${ }^{5}$

${ }^{1}$ Department of Women Health and Development, Maharajgunj Nursing Campus, Kathmandu, Nepal

${ }^{2}$ Department of Adult Health Nursing, School of Nursing, Chitwan Medical College, Nepal

${ }^{3}$ Department of Adult Health Nursing, Pokhara Nursing Campus, Pokhara, Nepal

${ }^{4}$ Department of Adult Health Nursing, Maharajgunj Nursing Campus, Kathmandu, Nepal

${ }^{5}$ Department of Psychiatric Nursing, Maharajgunj Nursing Campus, Kathmandu, Nepal

\author{
Received: 17 Aug, 2020 \\ Accepted: 7 Sept, 2020 \\ Published: 27 Sept, 2020 \\ Key words: Educational Environment; Nursing Stu- \\ dents; Perceptions; Postgraduate Programme. \\ *Correspondence to: Archana Pandey Bista, \\ Department of Women Health and Development, \\ Maharajgunj Nursing Campus, Maharajgunj, \\ Kathmandu, Nepal. \\ Email: archupb06@gmail.com \\ Citation \\ Bista AP, Sharma K, Tamrakar N, Sharma M, Bhatta- \\ rai T.Students' perception on educational environ- \\ ment of the postgraduate programme in selected \\ nursing colleges of Nepal. Journal of Chitwan Med- \\ ical College.2020;10(33):2-7.

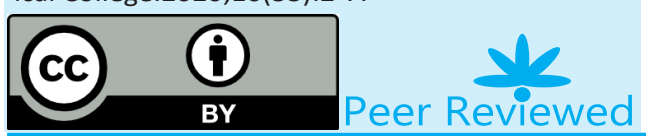

Conclusions: The findings indicate more positive perception on educational environment among postgraduate nursing students. Still some aspects such as teaching factual learning, memorizing learning, supportive students during stress, and social environment need to be emphasized to enhance the students' educational environment of post-graduate nursing program by the academic institution.

\section{INTRODUCTION}

The learning environment consists of the physical, educational, psychological and social context in which students play different significant roles for full filling their academic requirement and professional development. ${ }^{1}$ Students' entry to higher education brings about a series of changes at their affective, cognitive, professional and social levels. Globally rapid and continuous changes in the educational system of health professions including new programmes, curricula and strategies have increased the attention to improve the learning environment of all level students under universities. ${ }^{2}$ The purpose of higher education is to provide learning environment that guides the students toward academic achievements which promote their professional and personal lives. ${ }^{3,4}$.

At present different specialized courses have been incorporated in post graduate program in Nursing education creating challenges to educational institutions on the preparation of their graduates' students. ${ }^{5}$ Studies have found that many factors such as the physical environment, personal interest, teaching methodology, interpersonal relationships, and social environment influence teaching and learning process and its outcome for producing competent graduates to the society. Positive relationship have been observed between students positive perception of their learning environment and their academic- achievements. ${ }^{1,6-8}$

In order to evaluate learning environment previous studies have widely used Dundee Ready Education Environment Measure (DREEM) scale among medical and nursing students ${ }^{9-12}$ but its utilization among post graduate level of nursing program has not been well established. Thus this study aimed at finding the perception of educational environment of the postgraduates' students in different nursing colleges of Nepal.

\section{METHODS}

Descriptive cross-sectional design was adopted to find out the students' perception on educational environment of the postgraduate program in selected Nursing Colleges under Institute of Medicine, Tribhuvan University. All postgraduate nursing students who were studying in Maharajgunj Nursing Campus (MNC), Pokhara Nursing Campus (PNC), Chitwan Medical College School of Nursing (CMC-SON) and National Medical College (NMC), Birgunj were taken as study sample using complete 
enumeration technique. There were 104 master level nursing students in the selected colleges.

Ethical approval was obtained from Institute of Medicine Institutional Review Committee. Administrative approval for data collection was obtained from each nursing colleges. Data was collected from March 2019 to June 2019 by researchers themselves. Respondents were informed about the date of data collection and time was set on mutual plan consulting with their class coordinators. Written informed consent was taken from each respondent prior to data collection.

Perception of postgraduate students on their educational environment was measured by validated standard tool named Dundees Ready Educational Environment Measure (DREEM) developed by Roffs. DREEM is 50 items inventory, consisting of 5 subscales: Students' Perceptions of Learning (SPL)-12 items, Students Perception of Teachers (SPT)-11 items, Students' Academic Self-Perceptions (SASP)- 8 items, Perception of Atmosphere (SPA)- 12 items, and Students' Social Self-Perception (SSSP)-7 items. ${ }^{13}$ The responses were rated on a five-point
Likert scale, ranging from a minimum score of 0 (strongly disagree) to a maximum of 4 (strongly agree). The 50-item DREEM has a maximum score of 200 , indicating the ideal educational environment. DREEM questionnaires were distributed to the students after a brief explanation of the purpose of the study, and data collection process. They were requested to fill up the questionnaire in front of the researchers. They were also assured about anonymity and confidentiality of the information given by them. Also the name of the colleges were coded as college I, II, III and IV. Data were entered into Statistical Package for Social Science (SPSS) version 20 and were analysed by using DREEM author guide to assess the mean score and standard deviations on each subscale.

\section{RESULTS}

A total 104 master level $1^{\text {st }}$ and $2^{\text {nd }}$ year nursing students were participated from four selected nursing campuses. Among them, 41 students were from MNC, 29 students from PNC, 31 students from CMC-SON and 3 students from NMC, Birgunj Campus. All were female students.

Table 1: Students' level of perception on educational environment

( $n=104)$

\begin{tabular}{|c|c|}
\hline Level of Perception & Number (\%) \\
\hline \multicolumn{2}{|l|}{ Students' Perception of Learning } \\
\hline Very Poor (0-12) & - \\
\hline Teaching is Viewed Negatively (13-24) & $1(1.0)$ \\
\hline A more Positive Perception (25-36) & $85(81.7)$ \\
\hline Teaching highly thought of (37-48) & $18(17.3)$ \\
\hline \multicolumn{2}{|l|}{ Students' Academic Self Perception } \\
\hline Feeling of Total Failure (0-8) & - \\
\hline Many Negative Aspects (9-16) & $7(6.7)$ \\
\hline Feeling more on Positive Side (17-24) & $72(69.2)$ \\
\hline Confident (25-32) & $25(24.0)$ \\
\hline \multicolumn{2}{|l|}{ Students" Perception of Atmosphere } \\
\hline A Terrible Environment (0-12) & - \\
\hline There are many issues which needs change (13-24) & $8(7.7)$ \\
\hline A more positive Atmosphere (25-36) & $75(72.1)$ \\
\hline A good feeling Overall (37-48) & $21(29.2)$ \\
\hline \multicolumn{2}{|l|}{ Students' Perception of Teachers } \\
\hline Abysmal (0-11) & - \\
\hline In need of some retraining (12-22) & $9(8.6)$ \\
\hline Moving in the right direction (23-33) & $71(68.3)$ \\
\hline Model Teachers (34-44) & $24(23.1)$ \\
\hline \multicolumn{2}{|l|}{ Students' Social Self Perception } \\
\hline A Terrible Environment (0-12) & - \\
\hline There are many issues which needs change (13-24) & $9(8.7)$ \\
\hline A more positive Atmosphere (25-36) & $75(72.1)$ \\
\hline A good feeling Overall (37-48) & $21(20.2)$ \\
\hline \multicolumn{2}{|l|}{ Overall Perception } \\
\hline Very Poor (0-50) & - \\
\hline Plenty of Problems (51-100) & $1(1.0)$ \\
\hline More positive than negative (101-150) & $85(81.7)$ \\
\hline Excellent (150-200) & $18(17.3)$ \\
\hline
\end{tabular}


Most of the students overall perception on education environment was more positive than negative (81.7\%) and few (17.3\%) had excellent perception on their educational environment. Majorities of the students had more positive perception of learning (81.7\%), positive atmosphere (72.1\%), and social self-perception of positive atmosphere (72.1\%). Similarly, $68.3 \%$ of students' perceived that teachers are moving in the right direction and $23.1 \%$ perceived as model teachers. Still few students perceived many negative aspects in academic side (6.7\%), many issues which needs change in atmosphere (7.7\%) and social self-perception
$(8.7 \%)$ as well as they felt need of some retraining of teachers (8.6\%) (Table1).

Regarding students' perception on learning subscale, mean scores were higher on the aspects of teaching and also on learning abilities but less on aspect as teaching over-emphasizes factual learning. Likewise, on students perception of teaching subscales, mean scores were higher on aspect as teacher were knowledgeable followed by teachers communication skills than on aspect on teachers give relevant examples and well prepared on classes (Table 2).

Table 2: Students' scores on educational environment: perception of learning and teachers

\begin{tabular}{|c|c|c|}
\hline Items & Mean score \pm SD & Mean \% \\
\hline \multicolumn{3}{|l|}{ Perception of Learning:12 items } \\
\hline I am encouraged to participate in class & $3.37 \pm 0.55$ & 84.25 \\
\hline I am clear about the learning objectives of the course & $2.97 \pm 0.95$ & 74.25 \\
\hline The teaching encourages me to be an active learner & $2.98 \pm 0.63$ & 74.50 \\
\hline The teaching is often stimulating & $2.73 \pm 0.68$ & 68.25 \\
\hline The teaching is student centered & $2.71 \pm 0.99$ & 67.75 \\
\hline The teaching helps to develop my confidence & $2.68 \pm 0.93$ & 67.00 \\
\hline Teaching helps to develop my competence & $2.53 \pm 1.07$ & 63.25 \\
\hline The teaching is well focused & $2.64 \pm 0.85$ & 66.00 \\
\hline Teaching is too teacher centered & $2.68 \pm 1.03$ & 67.00 \\
\hline Long term learning is emphasized & $2.55 \pm 0.84$ & 63.75 \\
\hline The Teaching time is good / worthy & $2.41 \pm 0.96$ & 60.25 \\
\hline Teaching over-emphasizes factual learning & $1.67 \pm 0.90$ & 41.75 \\
\hline Total mean score & $31.92 \pm 5.1$ & 66.50 \\
\hline \multicolumn{3}{|l|}{ Perception of Teachers (11 items) } \\
\hline The teachers are knowledgeable & $3.14 \pm 0.614$ & 75.50 \\
\hline The teachers have good communication skills with students & $2.87 \pm 0.711$ & 71.75 \\
\hline The teachers are good at providing feedback to students & $2.82 \pm 0.93$ & 70.50 \\
\hline The teachers provides constructive criticism & $2.81 \pm 0.96$ & 70.25 \\
\hline The teachers ridicule to the students & $2.77 \pm 0.97$ & 69.25 \\
\hline The teachers gives clear examples & $2.75 \pm 0.81$ & 68.75 \\
\hline The teachers are patient with students & $2.67 \pm 0.86$ & 66.75 \\
\hline The teachers are well prepared for their class & $2.45 \pm 0.92$ & 61.25 \\
\hline The teachers are authoritarian & $1.66 \pm 1.12$ & 41.50 \\
\hline Students irritate the teacher & $2.75 \pm 0.81$ & 68.75 \\
\hline The teachers get angry in class & $2.82 \pm 0.96$ & 70.50 \\
\hline Total Score & $30.02 \pm 5.07$ & 68.23 \\
\hline
\end{tabular}

Among items of academic self-perception scale, students' mean scores were higher on aspects of confident about passing this year and learned a lot about empathy in their profession whereas less mean score was observed on aspect of memorizing all the needed and good preparation for this year work. Similarly, in the students' perception of atmosphere scale, mean scores were observed higher in the items of opportunities to develop interpersonal skills, and feel comfortable in class socially whereas lower in the item related to aspect of program is well time tabled (Table 3 ).

On students' social self-perception scale, students rated higher score on the aspects of having good friends in this campus and good social life whereas lower mean score was observed on feeling bored on this course (Table 4).

Students perception of learning was more positive (31.92/48), students perceptions of teachers was moving in the right direction (30.02/44), students' academic self/perception was feeling more on positive side (22.32/32), students' perceptions of atmosphere was a more positive atmosphere $(32.36 / 48)$ and their social selfperception was a more positive atmosphere (32.36). Highest score was found in subscales academic self-perception (69.75\%) and perception of teachers $(68.23 \%)$ whereas lowest score was found in social self-perception (63.64\%) (Table 5). 


\begin{tabular}{|c|c|c|}
\hline Statements & Mean Score $\pm S D$ & Mean \% \\
\hline \multicolumn{3}{|l|}{ Academic Self Perception (8 items) } \\
\hline I am confident about passing this year & $3.26 \pm 0.71$ & 81.5 \\
\hline I have learned a lot about empathy in my profession & $3.16 \pm 0.68$ & 79.0 \\
\hline Much of what I have to learn seems relevant to a career in health care & $2.92 \pm 0.75$ & 73.0 \\
\hline I feel I am being well prepared for my profession & $2.84 \pm 0.93$ & 71.0 \\
\hline My problem solving skills are being developed here & $2.73 \pm 0.76$ & 68.25 \\
\hline Learning strategies worked for me before work for me now & $2.60 \pm 0.83$ & 65.0 \\
\hline Last year's work has been a good preparation for this year work & $2.46 \pm 0.99$ & 61.5 \\
\hline I am able to memorize all I need. & $2.35 \pm 0.95$ & 58.75 \\
\hline Total Score & $22.32 \pm 3.54$ & 69.75 \\
\hline Statements: Students' Perceptions of Atmosphere (12 items) & Mean Score $\pm S D$ & \\
\hline Opportunities for me to develop interpersonal skills & $3.19 \pm 0.59$ & 79.75 \\
\hline I feel comfortable in class socially & $3.18 \pm 0.72$ & 79.50 \\
\hline The atmosphere is relaxed during lectures & $2.89 \pm 0.76$ & 72.25 \\
\hline The atmosphere is relaxed during the teaching & $2.80 \pm 0.86$ & 70.00 \\
\hline The atmosphere is relaxed during tutorials & $2.86 \pm 0.94$ & 71.5 \\
\hline I am able to concentrate well & $2.73 \pm 0.68$ & 68.25 \\
\hline Cheating is the problem in this college & $2.61 \pm 1.28$ & 65.25 \\
\hline I find the experience disappointing & $2.66 \pm 1.00$ & 66.50 \\
\hline The atmosphere motives me as a learner & $2.60 \pm 0.81$ & 65.00 \\
\hline The enjoyments outweighs the stress of studying nursing study & $2.12 \pm 1.03$ & 53.00 \\
\hline The program is well time tabled & $1.60 \pm 1.24$ & 40.00 \\
\hline I feel able to ask questions I want & $3.01 \pm 0.81$ & 75.25 \\
\hline Total & $32.26 \pm 5.1$ & 67.21 \\
\hline
\end{tabular}

Table 4: Students' scores on educational environment: social self-perception

(n=104)

\begin{tabular}{|c|c|c|}
\hline Statements: Social Self-Perception ( 7 items) & Mean Score \pm SD & Percentage \\
\hline I have good friends in this campus & $3.27 \pm 0.81$ & 81.75 \\
\hline My social life is good & $3.12 \pm 1.09$ & 78.00 \\
\hline I am too tired to enjoy this course & $2.46 \pm 1.09$ & 61.5 \\
\hline My accommodation is pleasant & $2.89 \pm 0.88$ & 72.25 \\
\hline There is a good support system for students who get stressed & $2.33 \pm 0.93$ & 58.25 \\
\hline I seldom feel lonely & $2.05 \pm 1.28$ & 51.25 \\
\hline I am rarely bored on this course & $1.70 \pm 1.17$ & 42.5 \\
\hline Total & $17.82 \pm 4.37$ & 63.64 \\
\hline
\end{tabular}

Table 5: Students' mean score and percentage in DREEM subscales

\begin{tabular}{|l|c|c|c|}
\hline DREEM Subscales & Maximum Score & Mean Score \pm SD & Percentages \\
\hline Students' Perception of Learning ( SPL) & 48 & $31.92 \pm 4.9$ & 66.50 \\
\hline Students' Perception of Teachers (SPT) & 44 & $30.02 \pm 5.07$ & 68.23 \\
\hline Students' Academic Self-perception (SASP) & 32 & $22.32 \pm 3.54$ & 69.75 \\
\hline Students' Perception of Atmosphere (SPA) & 48 & $32.36 \pm 5.1$ & 67.42 \\
\hline Students' Social Self Perception (SSSP) & 28 & $17.82 \pm 3.3$ & 63.64 \\
\hline Total DREEM Score & $\mathbf{2 0 0}$ & $\mathbf{1 3 4 . 3 7} \pm \mathbf{2 1}$ & $\mathbf{6 7 . 1 8}$ \\
\hline
\end{tabular}

\section{DISCUSSION}

Educational environment is very important for the medical students to get valuable achievement, satisfaction and success. Every educational institution put their effort to provide best possible learning environment and experience for their students. Students also play the vital role in the evaluation, implementation and enhancement of the quality of their educational environment. 
In this study, most of the students $(81.7 \%)$ rated more positive than negative perceptions and $17.3 \%$ had excellent perception on their educational environment. Overall mean score was $134.37 \pm 21$ out of 200 DREEM score, which indicates the positive learning environments. This finding is similar to the study done in a nursing college in Eastern Nepal among students in which overall mean score of nursing students was $131.25 \pm$ 15.82 out of $200 .{ }^{8}$ Similar result was also found in the study conducted at university of Malaysia where medical students' perception of learning environment was more positive than negative (135.6/200). ${ }^{14}$ Further other studies in Bangladesh ${ }^{15}$ and India ${ }^{16}$ revealed more positive than negative learning environment (110/200 and 123/200 total mean DREEM scores) for the undergraduate medical students.

Regarding five essential subscales of DREEM, students had more positive perception of learning (31.93/48). This is similar to the study by Said, Rogayan \& Halfizahamon among Malasiyan students where they found mean sore of $31.43 .{ }^{11}$ Other study in Malaysia was also revealed 33.04/48 score in the perception of learning. ${ }^{14}$ Here we found students perception of teachers was moved in the right direction(30.02/44). This findings is consistent with the findings of the study done by Koirala (2019) among under graduate students of Nursing, Institute of Medicine where the mean score on perception of teacher was 30.7 out of $44 .{ }^{13}$ Similar score was also reported in the done in Malaysia in which DREEM mean score on perception of teachers was $29.68 / 44 .{ }^{14}$

In this study, students had a more positive perception of atmosphere (32.26/48) and this finding is almost similar with the finding of Koirala (2019) in Kathmandu in which nursing students scores was 33.3 on this subscale. ${ }^{13}$ Concerning social self-perception, students reported that there are many issues which needs change $(17.82 / 28)$ and this findings is almost similar with the study done among nursing students of the Institute of Health Science, province no. 1 of Nepal which revealed

\subsection{3 score on this scale. ${ }^{8}$}

Further, item wise score signifies the lower score on items such as providing factual learning with examples, time management, well preparation for class and opportunities for increasing memories which are similar with the findings of studies done in Kathmandu and Dharan of Nepal. ${ }^{8,13}$

Despite overall positive perception, specifically we identified that students perceived that the teachers were authoritative, need to more time management for classes and the lack of good support system for the students at the time of stress. This findings is consistent with study conducted among nursing students in one of institution from Nepal which emphasized the need to consider these aspects among nursing programmes. ${ }^{8}$

Here we discerned that students' perception of social self -perception was lower than other aspects with low mean score . This finding is consistent with findings conducted among medical and nursing students in previous studies. ${ }^{8,13,14}$

\section{CONCLUSION}

Overall level of perception and overall obtained mean scores indicates the post graduate nursing students' positive perception on educational environment. Consequently, providing factual learning, time management, well preparation for class, opportunities for increasing memories and the aspects of social self-perception are shown to be the consideration areas for the enhancement of educational environment of the post graduate nursing students.

\section{CONFLICT OF INTEREST: None}

\section{FINANCIAL DISCLOSURE: None}

\section{REFERENCES:}

1. Ahmed Y, Tahha H. M, Alneel S, Gaffar A M. Students' perception of the learning environment and its relation to their study year and performance in Sudan. International Journal of Medical Education. 2018; 9:145-50. [DOI]

2. Bakhshialiabad H, Bakhshi M, Hassanshahi G. Students' perceptions of the academic learning environment in seven medical sciences courses based on DREEM. Adv Med Educ Pract.2015; 6:195-203. [DOI]

3. Messas J T, Leonello V M. Fernandees M, Costa G, Bucchi,S \& MiraV. The educational environment of the undergraduate nursing course from the student perspective. Journal of School of Nursing. 2015; 49: 104-112. [DOI]

4. Victor G, Ishtiaq M, Parveen S. Nursing students perception of their educational environment in the bachelor's program of the Shiffa College of Nursing, Pakistan. Journal of Educational Evaluation for Health Professions. 2016; 13 (43): 1-6. [DOI]

5. Nepal Health Research Council (NHRC). 2010. Report on Status of Nurses in Nepal .Ramshahpath, Kathmandu Nepal

6. Hakim A. Nursing students' satisfaction about their field of study. Interna- tional journal on Nursing .2014; 2 (2): 14-21. [PMID]

7. Tontus H. DREEM; dreams of the educational environment as its effect on education results of 11 medical faculties of Turkey. Journal of Experimental and Clinical Medicine. 2010.27; 104-108. [DOI]

8. Shrestha E, Mehata RS, Mandal G, Chaudhary K, Pradhan N. Perception of the learning environment among the students in a nursing college in Eastern Nepal. BMC Medical Education.2019; 19 (382) : 2-7. [DOl]

9. Roff S, McAleer S, Harden RM, Al-Qahtani M, Ahmed AU, Deza H, Groenen $\mathrm{G}$, et al. Development and validation of the Dundee ready education environment measure (DREEM). Med Teach.1997; 19: 295-99. [DOI]

10. Chen H, Lo Hs. Development and psychometric testing of the nursing student satisfaction scale for the associate nursing programs. Journal of Nursing Education and Practice. 2012; 2 (3):25-37. [LINK]

11. Said M N, Rogyah J, Hazflizah A. Learning Environments in the Kulliyyah (Faculty) of Nursing. International Islamic University Malaysia. Malayasian Journal of Medical Sciences. 2009; 16 (4):15-24. [PMID]

12. Hamid B, Faroukh A, Mohammadhosein B. Nursing students' perceptions of their educational environment based on DREEM Model in an Iranian university. Malaysian Journal of Medical Sciences. 2013; 20 (4) :56-63. [PMID] 
13. Koirala M, Koirala S \& Neupane S. Perception of nursing students towards academic learning environment in a college of Kathmandu. Journal of Institute of Medicine. 2019; 41(1):91-101. [DOI]

14. Ugusman A, Othman N, Razak Z et al. Assessment of learning environment among first year Malaysian medical students. Journal of Taibah University Medical Sciences. 2015; 10, (4): 454-60. [DOI]
15. Nahar N, Talukder MHK, Khan, MTH, Mohammad S, Nargis T. Students perception of educational environment of medical colleges in Bangladesh. Journal of Bangabandhu Sheikh Mujib Medical University. 2010; 3 (2): 97-102. [DOI]

16. Pai PG, Menezees V, Shreekanth, Subramanian AM, Shenoy JP. Medical students' perceptions of their educational environment. Journal of Clinical and Diagnostic Research. 2014; 8 (1):103-07. [DOI] 